\title{
Co-ingestion of whey protein hydrolysate with milk minerals rich in calcium potently stimulates glucagon-like peptide-1 secretion: an RCT in healthy adults
}

\author{
Yung-Chih Chen ${ }^{1,2}$ • Harry A. Smith ${ }^{1}$. Aaron Hengist ${ }^{1}$ - Oliver J. Chrzanowski-Smith ${ }^{1}$. Ulla Ramer Mikkelsen ${ }^{3}$. \\ Harriet A. Carroll ${ }^{1,4}$. James A. Betts ${ }^{1}$. Dylan Thompson ${ }^{1} \cdot$ John Saunders ${ }^{1,5}$ • Javier T. Gonzalez ${ }^{1}$ (1)
}

Received: 26 February 2019 / Accepted: 11 September 2019 / Published online: 17 September 2019

(c) The Author(s) 2019

\begin{abstract}
Purpose To examine whether calcium type and co-ingestion with protein alter gut hormone availability.

Methods Healthy adults aged $26 \pm 7$ years (mean \pm SD) completed three randomized, double-blind, crossover studies. In all studies, arterialized blood was sampled postprandially over $120 \mathrm{~min}$ to determine GLP-1, GIP and PYY responses, alongside appetite ratings, energy expenditure and blood pressure. In study $1(n=20)$, three treatments matched for total calcium content (1058 mg) were compared: calcium citrate (CALCITR); milk minerals rich in calcium (MILK MINERALS); and milk minerals rich in calcium plus co-ingestion of $50 \mathrm{~g}$ whey protein hydrolysate (MILK MINERALS + PROTEIN). In study $2(n=6), 50 \mathrm{~g}$ whey protein hydrolysate (PROTEIN) was compared to MILK MINERALS + PROTEIN. In study $3(n=6)$, MILK MINERALS was compared to the vehicle of ingestion (water plus sucralose; CONTROL).

Results MILK MINERALS + PROTEIN increased GLP-1 incremental area under the curve (iAUC) by $\sim$ ninefold $\left(43.7 \pm 11.1\right.$ pmol L $\left.{ }^{-1} 120 \mathrm{~min} ; p<0.001\right)$ versus both CALCITR and MILK MINERALS, with no difference detected between CALCITR $\left(6.6 \pm 3.7 \mathrm{pmol} \mathrm{L}{ }^{-1} 120 \mathrm{~min}\right)$ and MILK MINERALS $\left(5.3 \pm 3.5 \mathrm{pmol} \mathrm{L}^{-1} 120 \mathrm{~min} ; p>0.999\right)$. MILK MINERALS + PROTEIN produced a GLP-1 iAUC 25\% greater than PROTEIN ( $p=0.024$; mean difference: $9.1 \pm 6.9 \mathrm{pmol} \mathrm{L}^{-1} 120 \mathrm{~min}$ ), whereas the difference between MILK MINERALS versus CONTROL was small and nonsignificant ( $p=0.098$; mean difference: $4.2 \pm 5.1 \mathrm{pmol} \mathrm{L}^{-1} 120 \mathrm{~min}$ ).

Conclusions When ingested alone, milk minerals rich in calcium do not increase GLP-1 secretion compared to calcium citrate. Co-ingesting high-dose whey protein hydrolysate with milk minerals rich in calcium increases postprandial GLP-1 concentrations to some of the highest physiological levels ever reported. Registered at ClinicalTrials.gov: NCT03232034, NCT03370484, NCT03370497.
\end{abstract}

Keywords Incretins $\cdot$ Calcium $\cdot$ Protein $\cdot$ Metabolism $\cdot$ Peptide tyrosine tyrosine $\cdot$ Gastric inhibitory polypeptide . Postprandial

Electronic supplementary material The online version of this article (https://doi.org/10.1007/s00394-019-02092-4) contains supplementary material, which is available to authorized users.

Javier T. Gonzalez

J.T.Gonzalez@bath.ac.uk

1 Department for Health, University of Bath, Bath BA2 7AY, UK

2 Department of Physical Education, National Taiwan Normal University, Taipei, Taiwan

3 Arla Foods Ingredients Group P/S, Viby J, Denmark

4 Rowett Institute, University of Aberdeen, Aberdeen, UK

5 Royal United Hospitals Bath NHS Foundation Trust, Bath, UK

\author{
Abbreviations \\ GLP-1 Glucagon-like peptide-1 \\ GIP Glucose-dependent insulinotropic polypeptide \\ PYY Peptide tyrosine-tyrosine \\ iAUC Incremental area under the curve
}

\section{Introduction}

Glucagon-like peptide-1 (GLP-1) is a gut hormone involved in metabolism, insulin secretion, appetite, and angiogenesis [1-3], and it is thought to contribute to the preservation of metabolic health. For example, increasing postprandial GLP-1 concentrations can protect against glucose 
intolerance during weight gain in rodents [4]. Consequently, strategies such as bariatric surgery, GLP-1 analogues and dipeptidyl peptidase-IV inhibitors (that increase the activity of GLP-1) to augment circulating GLP-1 availability/action are of great interest for the prevention/treatment of obesity and obesity-related diseases [1]. Whilst these surgical and pharmacological strategies hold some potential to elevate GLP-1 availability/action and thus improve metabolic health and or weight loss, many strategies are either not cost-effective for large-scale use and/or carry risks of harmful or undesirable side-effects $[1,5]$. Therefore, nutritional strategies to augment GLP-1 availability may provide an attractive additional or alternative option to current approaches.

Nutrition potently regulates enteroendocrine cell action and therefore gut hormone secretion. For example, the ingestion of protein increases plasma GLP-1 availability [6, 7]. The mechanism(s) by which dietary protein stimulates GLP-1 availability is thought to involve direct stimulation by amino acids of the calcium-sensing receptor expressed on L-cells in the intestine [8]. Importantly, it has now been shown across in vitro $[9,10]$, ex vivo [8] and in vivo rodent models [11] that the calcium-sensing receptor regulates gut hormone release and is responsive to physiologically relevant extracellular calcium and amino acid concentrations across fasting to postprandial concentration range. However, to date, no study has demonstrated the synergistic effect of protein and calcium ingestion on GLP-1 availability in humans.

The role of dietary calcium in gut hormone secretion is being increasingly revealed. Both acute and chronic supplementation with calcium has been shown to augment plasma GLP-1 availability in humans [12, 13], however not all studies have shown an effect of calcium on plasma GLP-1 availability [7, 14, 15]. This discrepancy could be explained (in part) by differences in the type of calcium and/or co-ingestion with other nutrients, leading to variable calcium concentrations in the ileum, where GLP-1 is primarily secreted [16]. Since most calcium is absorbed in the duodenum/jejunum, oral calcium ingestion does not necessarily achieve ileal calcium concentrations in humans that maximize potential for protein-induced GLP-1 secretion [8, $16,17]$. Since there is evidence that milk-based sources of calcium (e.g., calcium phosphate and the associated minerals that are co-ingested with milk) are more slowly absorbed than other sources of calcium, such as calcium citrate [18, 19], it could be hypothesized that milk minerals rich in calcium expose the ileum to greater concentrations of calcium than calcium citrate, leading to increased GLP-1 secretion, but this remains to be tested.

Accordingly, the collective aim of this series of studies was to assess whether milk sources of calcium increase plasma GLP-1 availability to a greater extent than calcium citrate, and whether calcium-stimulated GLP-1 availability is dependent on the co-ingestion of protein. Since dietary calcium and protein have also been implicated in the secretion of other gut hormones (e.g., glucose-dependent insulinotropic polypeptide, GIP and peptide tyrosine-tyrosine, PYY), and in metabolism, appetite and blood pressure, we also aimed to assess the effects of calcium (type) and protein co-ingestion on GIP and PYY availability, energy expenditure and glycaemia, appetite ratings and blood pressure.

\section{Methods}

\section{Study design}

The present project comprised a series of three acute experiments with identical outcome variables and the recruitment of participants used identical inclusion and exclusion criteria. The only differences between experiments were the treatment conditions and number of participants, as described below. Each experiment was registered at ClinicalTrials.gov (IDs: NCT03232034; NCT03370484; NCT03370497) and was conducted in a randomized (randomization performed by J.T.G. using an online program, randomizer.org), double-blind (the lead investigator Y.C.C and participants were blinded during interventions) crossover design at the University of Bath, UK.

\section{Study 1}

Study 1 comprised three trials: (1) calcium citrate $[4380 \mathrm{mg}$ to provide $1000 \mathrm{mg}$ calcium; CALCITR (NOW foods, Bloomingdale, IL, USA)]; (2) calcium-enriched milk mineral supplement [3745 $\mathrm{mg}$ to provide $1000 \mathrm{mg}$ calcium; MILK MINERALS; Capolac ${ }^{\circledR}$ (Arla Foods Ingredients, Viby J, Denmark); or (3) calcium-enriched milk mineral supplement $(2050 \mathrm{mg}$ to correct for calcium content in protein) plus whey protein hydrolysate $[58.8 \mathrm{~g}$ providing $50 \mathrm{~g}$ protein and $453 \mathrm{mg}$ calcium; MILK MINERALS + PROTEIN; Lacprodan ${ }^{\circledR}$ DI-3065; (Arla Foods Ingredients, Viby J, Denmark)]. Each of these drinks also contained $500 \mathrm{~mL}$ of water and artificial sweetener [ $80 \mathrm{mg}$ sucralose (MyProtein, Northwich, UK); Table 1]. This quantity of sucralose was not expected to stimulate gut hormone secretion, since ingestion of either $80 \mathrm{mg}$ or $800 \mathrm{mg}$ sucralose does not alter incretin hormone or glucose responses [20]. The calcium content of the supplements and of the tap water was independently verified using a commercially available assay (abcam, Cambridge, UK). The day-to-day variation in the calcium content of the tap water was $<15 \mathrm{mg}$ and is, therefore, unlikely to have been sufficient to alter the responses observed. Whilst the MILK MINERALS contained a variety of additional nutrients compared to CALCITR, these were relatively minor (protein, lactose and fat all $<0.5 \mathrm{~g}$ and 
Table 1 Nutritional composition of each treatment

\begin{tabular}{llllll}
\hline Ingredient & \multicolumn{2}{l}{ Treatment } & & \\
\cline { 2 - 6 } & CONTROL $^{\mathrm{a}}$ & CALCITR $^{\mathrm{b}}$ & $\begin{array}{l}\text { MILK } \\
\text { MINERALS }\end{array}$ & PROTEIN $^{\mathrm{d}}$ & $\begin{array}{l}\text { MILK MINER- } \\
\text { ALS + PRO- } \\
\text { TEIN }\end{array}$ \\
\hline Energy (kJ) & $<1$ & $<1$ & $<5$ & 863 & 858 \\
Water (mL) & 500 & 500 & 500 & 500 & 500 \\
Sucralose (mg) & 80 & 80 & 80 & 80 & 80 \\
Calcium (mg) & 58 & 1058 & 1058 & 453 & 1058 \\
Phosphorus (mg) & $<1$ & $<1$ & 551 & 686 & 686 \\
Magnesium (mg) & $<1$ & $<1$ & 26 & 26 & 26 \\
Protein (g) & $<0.1$ & $<0.1$ & $<0.1$ & 50 & 50 \\
Carbohydrate (g) & $<0.1$ & $<0.1$ & 0.3 & 1.8 & 1.5 \\
Fat (g) & $<0.1$ & $<0.1$ & $<0.1$ & $<0.1$ & $<0.1$ \\
\hline
\end{tabular}

${ }^{\mathrm{a}}$ CONTROL, vehicle of ingestion

${ }^{\mathrm{b}} \mathrm{CALCITR}$, calcium citrate

${ }^{\mathrm{c}}$ MILK MINERALS, milk minerals rich in calcium

${ }^{\mathrm{d} P R O T E I N}$, whey protein hydrolysate sodium, magnesium, chloride and potassium all $<90 \mathrm{mg}$ ). Therefore, the primary nutritional difference is the phosphorus content of MILK MINERALS (Table 1). These products were batch-tested by the manufacturer to confirm the nutritional composition.

\section{Study 2}

Study 2 aimed to assess whether the addition of calciumenriched milk minerals rich in calcium supplement to whey protein hydrolysate enhances gut hormone secretion, compared to the ingestion of whey protein hydrolysate alone. This experiment involved two trials: PROTEIN (58.8 $\mathrm{g}$ to provide $50 \mathrm{~g}$ protein) and MILK MINERALS + PROTEIN (2050 mg calcium-enriched milk mineral supplement plus $58.8 \mathrm{~g}$ whey protein hydrolysate powder to provide $1000 \mathrm{mg}$ calcium plus $50 \mathrm{~g}$ protein), whereby the PROTEIN condition included ingestion of $50 \mathrm{~g}$ whey protein hydrolysate, mixed in $500 \mathrm{~mL}$ water and artificial sweetener $(80 \mathrm{mg}$ sucralose; Table 1). Since the whey protein hydrolysate already contained $453 \mathrm{mg}$ calcium, the difference in calcium content between MILK MINERALS + PROTEIN versus PROTEIN, was $600 \mathrm{mg}$ (Table 1).

\section{Study 3}

The third and final study in this series comprised two trials: CONTROL and MILK MINERALS to establish the effect of calcium-enriched milk minerals rich in calcium supplement ingestion in the absence of protein, on gut hormones responses (Table 1). The calcium content in the CONTROL condition is the background calcium present in the drinking water of the laboratory.

\section{Participants}

Twenty healthy adult men and women (Table 2) were recruited via word-of-mouth and poster advertisement at the University of Bath. All participants completed the treatments comprising study 1 . Of this full sample, two subgroups (each $n=6$ ) were randomly allocated additional treatments (PROTEIN or CONTROL) for studies 2 and 3 (CONSORT checklist is provided as Supplementary Online Material). Exclusion criteria included: weight instability as defined by $>3 \%$ change in body mass in the previous 3 months; any previous or current metabolic, cardio-pulmonary or musculoskeletal diseases; smoking within the last 4 months; not between

Table 2 Participant characteristics

\begin{tabular}{llll}
\hline & Study 1 & Study 2 & Study 3 \\
\hline Sample size (of which female) & $20(6)$ & $6(2)$ & $6(2)$ \\
Age (years) & $26 \pm 7$ & $25 \pm 4$ & $24 \pm 4$ \\
Body mass (kg) & $73.9 \pm 9.8$ & $72.5 \pm 7.0$ & $71.2 \pm 9.3$ \\
Body mass index $\left(\mathrm{kg} \mathrm{m}^{-2}\right)$ & $23.7 \pm 2.4$ & $23.8 \pm 2.5$ & $22.8 \pm 2.0$ \\
Waist circumference $(\mathrm{cm})$ & $80 \pm 9$ & $77 \pm 5$ & $74 \pm 6$ \\
$\begin{array}{l}\text { Hip circumference }(\mathrm{cm}) \\
\text { Resting metabolic rate }\end{array}$ & $99 \pm 6$ & $98 \pm 3$ & $98 \pm 2$ \\
$\quad\left(\mathrm{MJ} \mathrm{day}^{-1}\right)$ & $7.06 \pm 0.95$ & $6.86 \pm 0.86$ & $6.89 \pm 0.85$ \\
$\begin{array}{l}\text { Fasting RER } \\
\text { Systolic blood pressure }\end{array}$ & $115 \pm 6$ & $113 \pm 7$ & $115 \pm 5$ \\
$\quad\left(\mathrm{mmHg}_{2}: \dot{V} \mathrm{O}_{2}\right)$ & $0.88 \pm 0.04$ & $0.86 \pm 0.02$ & $0.88 \pm 0.06$ \\
$\begin{array}{l}\text { Diastolic blood pressure } \\
(\mathrm{mmHg})\end{array}$ & $73 \pm 4$ & $71 \pm 3$ & $72 \pm 3$ \\
\hline
\end{tabular}

Values are mean \pm SD. $n=20$ for study $1 . n=6$ for studies 2 and 3 $R E R$ respiratory exchange ratio 
the ages of 18-65 years; a body mass index (BMI) below $18.5 \mathrm{~kg} / \mathrm{m}^{2}$ or above $30 \mathrm{~kg} / \mathrm{m}^{2}$; planned to change lifestyle (diet and/or physical activity) during the study period; or were not willing to refrain from alcohol containing drinks or unaccustomed exercise 1 day before the laboratory sessions. The study protocols were approved by University of Bath, Research Ethics Approval Committee for Health (REACH) (reference number: EP 16/17 164). All participants provided written, informed consent prior to participation in the study, which was conducted in accordance with the Declaration of Helsinki.

\section{Pre-trial standardization}

Participants were asked to record their diet and physical activity for $24 \mathrm{~h}$ prior to the first trial and were asked to replicate this diet and physical activity pattern for $24 \mathrm{~h}$ prior to all subsequent trials. Tea, coffee and alcohol were not allowed $24 \mathrm{~h}$ before the trials and participants were asked to refrain from any vigorous physical activity/exercise $24 \mathrm{~h}$ before the trials (confirmed verbally with participants upon subsequent trials). Women who were not on hormonal contraceptives were tested during the follicular phase of the menstrual cycle (3-12 days after the first menses). For women taking hormonal contraceptives, and all men the wash-out period between trials was between $48 \mathrm{~h}$ and 7 days.

\section{Trial days}

Participant reported to the laboratory at the University of Bath between 08:00-09:00 $\mathrm{h}$ following a 10-12-h overnight fast (standardized within participants). After measurement of body mass, waist and hip circumference, participants rested on a bed for $10 \mathrm{~min}$ before determination of blood pressure and resting metabolic rate (RMR) via 5-min samples of expired gas using the Douglas bag technique [21]. To allow for participants to become accustomed to the mouthpiece, this was given to participants $5 \mathrm{~min}$ prior to each sample collection. Barometric pressure was $734 \pm 5 \mathrm{mmHg}$, $735 \pm 5 \mathrm{mmHg}, 734 \pm 6 \mathrm{mmHg}, 735 \pm 6 \mathrm{mmHg}$ and $736 \pm 3 \mathrm{mmHg}$ on CALCITR, MILK MINERALS, MILK MINERALS + PROTEIN, PROTEIN and CONTROL trials, respectively. Ambient temperature was $23 \pm 1{ }^{\circ} \mathrm{C}, 22 \pm 1{ }^{\circ} \mathrm{C}$, $23 \pm 1{ }^{\circ} \mathrm{C}, 22 \pm 1{ }^{\circ} \mathrm{C}$ and $23 \pm 1{ }^{\circ} \mathrm{C}$ on CALCITR, MILK MINERALS, MILK MINERALS + PROTEIN, PROTEIN and CONTROL trials, respectively.

Arterialized venous blood samples were obtained by catheterization of a pre-heated dorsal hand vein as previously described [22]. After a baseline blood sample and appetite scale, test drinks were consumed within a 5-min window, followed by a 120 -min observation period (commenced upon the first ingested mouthful of the test drink). Blood samples were taken at 15, 30, 45, 60, 90 and 120-min following consumption of the test drinks. Appetite visual analogue scales were obtained at baseline and every $30 \mathrm{~min}$ throughout the postprandial period. Expired gas collection and blood pressure were taken at 60 and 120 min after test drink consumption.

\section{Blood sampling and analysis}

A 10-mL blood sample was taken at each time point and allocated into tubes containing ethylenediaminetetraacetic acid (EDTA) (Sarstedt Ltd, Leicester, UK). Plasma samples were centrifuged immediately at $3465 \mathrm{~g}$ at $4{ }^{\circ} \mathrm{C}$ for $10 \mathrm{~min}$ and stored at $-80^{\circ} \mathrm{C}$ before performing analyses. Plasma glucose concentrations were determined using an automated analyzer (Daytona, Randox Laboratories) according to manufacturer's instructions.

Plasma GLP-1 $1_{\text {Total }}$, GIP Total $_{\text {and PYY }}$ Total were measured using commercially available enzyme-linked immunosorbent assays (ELISA; all from Merck Millipore Ltd. Watford, UK). The antibodies in the GLP-1 assay employed are specific to both GLP- $1_{7-36}$ and GLP- $1_{9-36}$ and therefore this assay captures GLP- $1_{\text {Total }}$ concentrations. We assessed GLP- $1_{\text {Total }}$, rather than GLP- $1_{7-36}$, since this is the best indication of GLP-1 secretion in humans [3, 23]. Furthermore, the recovery is $90-110 \%$, with a sensitivity of $1.5 \mathrm{pmol} \mathrm{L}^{-1}$, and there is no significant cross-reactivity with GLP-2, GIP, glucagon or oxyntomodulin [24]. The intra-assay and interassay coefficients of variation in our laboratory are $<9 \%$ and $<12 \%$, respectively.

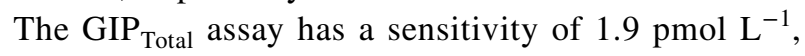
intra-assay and inter-assay coefficients of variation of $<10 \%$ and $<10 \%$, respectively. The PYY $\mathrm{Potal}_{\text {Tal }}$ assay has a sensitivity of $0.35 \mathrm{pmol} \mathrm{L}^{-1}$ intra-assay and inter-assay coefficients of variation of $<8 \%$ and $<12 \%$, respectively.

\section{Expired breath analysis}

Indirect calorimetry was performed using the Douglas bag method to assess energy expenditure and respiratory exchange ratio. A mouthpiece connected to a two-way, nonrebreathing valve (model 2730, Hans Rudolph, Kansas City, Missouri) was used to collect gas samples in Douglas bags, which were analyzed for concentrations of oxygen and carbon dioxide using paramagnetic and infrared transducers, respectively (Sevomex 5200S, Crowborough, East Sussex, UK). The ambient air was also analyzed at each time point to correct for changes in inspired gas concentrations [25]. Sensors were turned on $30 \mathrm{~min}$ prior to a two-point calibration (zero: $100 \%$ nitrogen; span: $16.93 \%$ oxygen and $5.04 \%$ carbon dioxide) using certified gases (BOC Industrial Gases, Linde AG, Munich, Germany).

Expired gas samples were corrected to standard temperature and pressure (dry) using a Fortin barometer (F.D. 
and company, Watford, UK). Volume and temperature of expired gas samples were determined using a dry gas meter (Harvard Apparatus, Edenbridge, Kent, UK) and thermistor (model 810-080, ETI, Worthing, UK), respectively, during gas evacuation.

\section{Blood pressure}

Systolic and diastolic blood pressure were determined in triplicate using an automated blood pressure monitor, and the arm was standardized within participants (Panasonic EW3106 W, Osaka, Japan).

\section{Subjective appetite ratings}

Subjective appetite was assessed using validated $100 \mathrm{~mm}$ visual analogue scales [26]. The questions asked were "how hungry do you feel" (with anchors: "I am not hungry at all" and "I have never been more hungry"), "how full do you feel" (with anchors: "Not at all full" and "Totally full"), "how satisfied do you feel" (with anchors: "I am completely empty" and "I cannot eat another bite") and "how much do you think you can eat" (with anchors: "Nothing at all" and "A lot"). These were combined into an overall appetite rating, as previously described [27].

\section{Power calculations}

Three sample size estimations were performed for the primary outcomes of each component study on the basis of GLP-1 responses as follows

\section{Study 1: CALCITR versus MILK MINERALS versus MILK MINERALS + PROTEIN}

Since it is hypothesised that calcium citrate should be absorbed in the intestine more proximally than calcium phosphate (and thus provide calcium to proximal versus distal components of the intestine), the sample size for study 1 was determined using plasma iAUC for GLP-1 ${ }_{7-36}$ (in the absence of relevant data on GLP- $1_{\text {Total }}$ ) in response to jejunal vs gastric feeding of mixed-macronutrients [28]. Jejunal vs gastric feeding produces a plasma GLP- $1_{7-36}$ iAUC of $2.0 \pm 1.4$ vs $1.0 \pm 1.3 \mathrm{~mol} \mathrm{~L}^{-1} \times 720 \mathrm{~min}$, respectively. Based on this effect size $(d z=0.83), 20$ participants will provide $>80 \%$ power to statistically detect this effect with an $\alpha$-level of 0.05 in a three-way crossover design.

This sample size was also deemed sufficient to detect changes between MILK MINERALS and MILK MINERALS + PROTEIN on the basis that protein delivered at a rate of $1.5 \mathrm{kcal} \mathrm{min}^{-1}$ to the duodenum results in a 60 -min area under the curve for plasma GLP- $1_{\text {Total }}$ of $1904 \pm 138 \mathrm{pmol} \mathrm{L}^{-1}$ min, compared to
$1490 \pm 109 \mathrm{pmol} \mathrm{L}^{-1}$ min with saline control [29]. Based on this effect size $(d z=0.96), 20$ participants should provide $>80 \%$ power to detect a similar effect size in a crossover design with three arms at an $\alpha$-level of 0.05 .

\section{Study 2: PROTEIN versus MILK MINERALS + PROTEIN}

The sample size estimation for the comparison of PROTEIN versus MILK MINERALS + PROTEIN was based on data from Mace et al. [8], where amino acid-induced GLP-1 secretion from an isolated rodent intestine is $\sim 130 \pm 127 \mathrm{pg} \mathrm{mL}(\mathrm{g} \text { dry weight })^{-1} \times \min$ in low extracellular calcium concentrations [8]. When the extracellular calcium concentration is increased to that seen in the human ileum after a high-calcium meal [17], amino acid-induced GLP-1 secretion is increased to $\sim 450 \pm 71 \mathrm{pg} \mathrm{mL}$ (g dry weight $)^{-1} \times \min [8]$. Using this effect size $(\mathrm{d} z=3.11)$, four participants would provide greater than $80 \%$ power to detect this effect with an $\alpha$-level of 0.05 .

\section{Study 3: CONTROL versus MILK MINERALS}

The sample size estimation for the comparison of CONTROL versus MILK MINERALS was also based on data from Mace et al. [8], whereby, in the absence of amino acids and under conditions of low extracellular calcium concentrations, GLP-1 secretion is $\sim 95 \pm 28 \mathrm{pg} \mathrm{mL}$ (g dry weight $)^{-1} \min$ [17]. When the extracellular calcium concentration is increased to that seen in the human ileum after a high-calcium meal [17], GLP-1 secretion is increased to $\sim 155 \pm 42 \mathrm{pg} \mathrm{mL}$ (g dry weight) ${ }^{-1}$ min [8]. Using this effect size $(\mathrm{d} z=1.68), 6$ participants should provide greater than $80 \%$ power to detect such an effect with an $\alpha$-level of 0.05 .

\section{Statistical analysis}

Statistical analyses were performed using GraphPad Prism v7 (GraphPad Software, San Diego, CA, USA). Values are mean \pm SD in text, and means $\pm 95 \%$ confidence intervals in figures, unless stated otherwise. Due to technical issues in analysis, PYY data are $n=16$ rather than $n=20$ for study 1. Postprandial hormone and appetite responses were converted into incremental area under the curve (iAUC) and total area under the curve (AUC) using the trapezoidal rule. Data were checked for normal distribution by histograms of residuals and the Shapiro-Wilk normality test prior to analysis. There was no evidence of non-normal distribution and therefore parametric statistics were employed on all variables. Time-dependent variables were assessed by two-way (time $\times$ treatment) repeated-measures ANOVA. Differences between treatments in non-time-dependent variables (e.g., AUC and iAUC) were assessed by one-way ANOVA and 
Bonferonni-corrected $t$ tests. Comparisons were considered to be significantly different when adjusted $p$ values were $\leq 0.05$. Since the studies were powered for gut hormone responses, and additional measures such as energy expenditure, appetite and blood pressure can be more variable, it was chosen to only present these additional data for study 1 $(n=20)$, due to a potential lack of power to make inferences regarding these variables in studies 2 and 3 . However, these data are included in the online supplemental data (Supplementary Data File 1) for use in post-publication analyses such as meta-analyses. Some secondary outcomes were listed on the clinical trials registry, but were not analyzed due to lack of resource. These were plasma TAG, serum NEFA, and serum insulin concentrations.
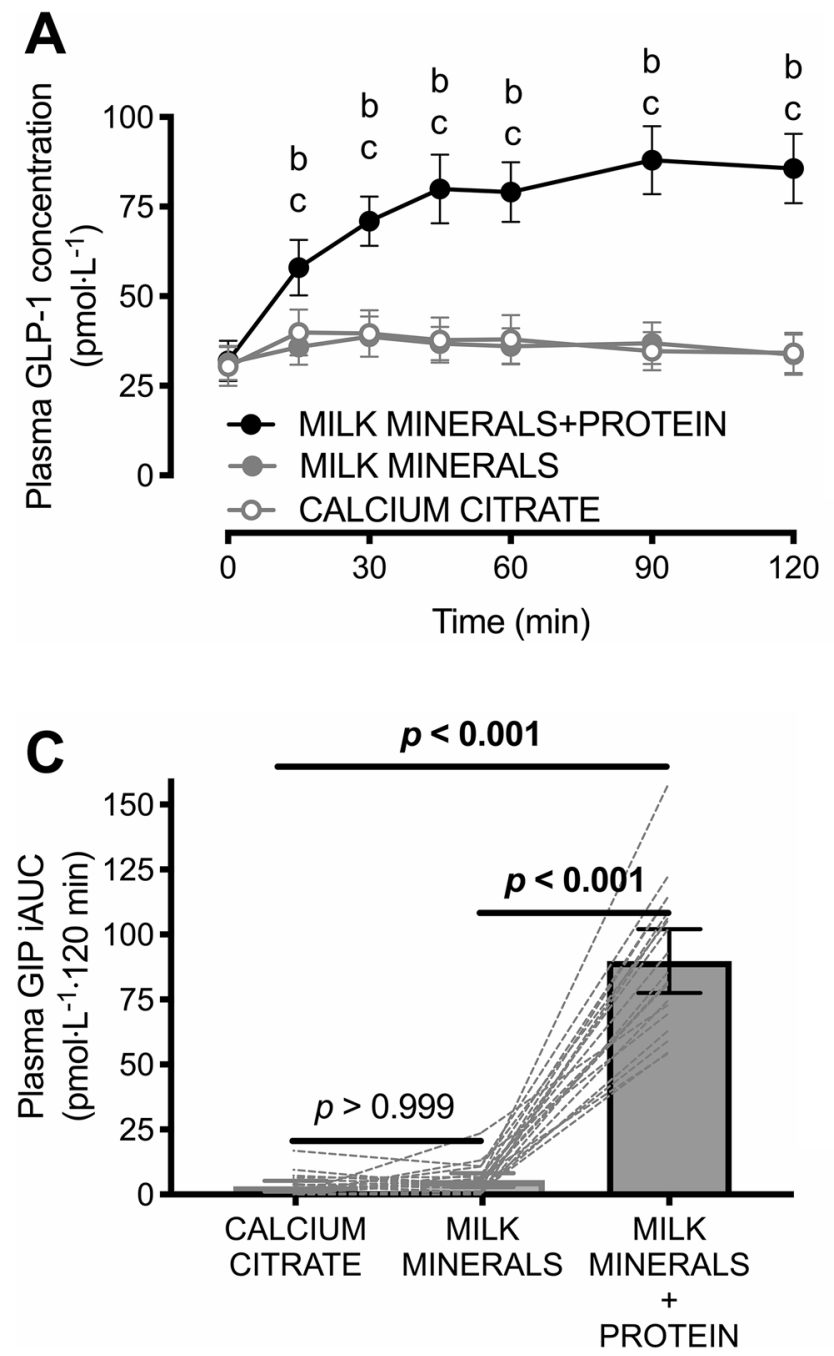

Fig. 1 Plasma GLP-1 concentrations (a) and time-average incremental area under the curve (iAUC) values for plasma GLP-1 (b), GIP (c) and PYY (d) following ingestion of calcium citrate, milk minerals rich in calcium (MILK MINERALS) and MILK MINERALS plus whey protein hydrolysate (MILK MINERALS + PROTEIN) in healthy men and women. Data are means $\pm 95 \% \mathrm{CI}, n=20$ for all data

\section{Results}

\section{Study 1: MILK MINERALS + PROTEIN versus MILK MINERALS versus CALCITR}

Plasma GLP-1, GIP and PYY concentrations did not differ at baseline (all $p>0.999$ ). Main effects of time and of treatment were both detected (both $p<0.001$ ), in addition to a time $\times$ treatment interaction effect $(p<0.001)$ for the postprandial change in plasma GLP-1 (Fig. 1a). This resulted in a GLP-1 iAUC that was $\sim$ ninefold higher with MILK MINERALS + PROTEIN compared to both CALCITR and MILK MINERALS (Fig. 1b; both $p<0.001$ ). Peak GLP-1

B

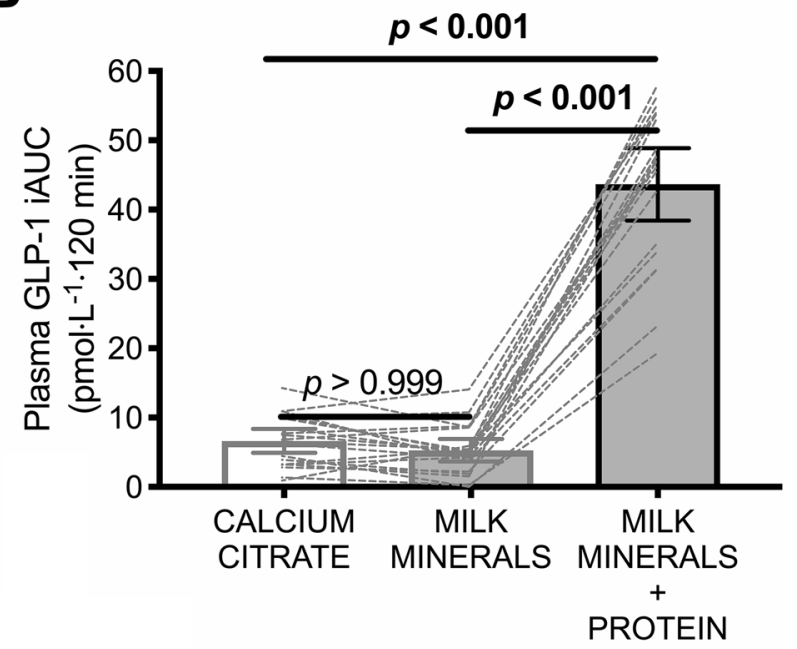

D

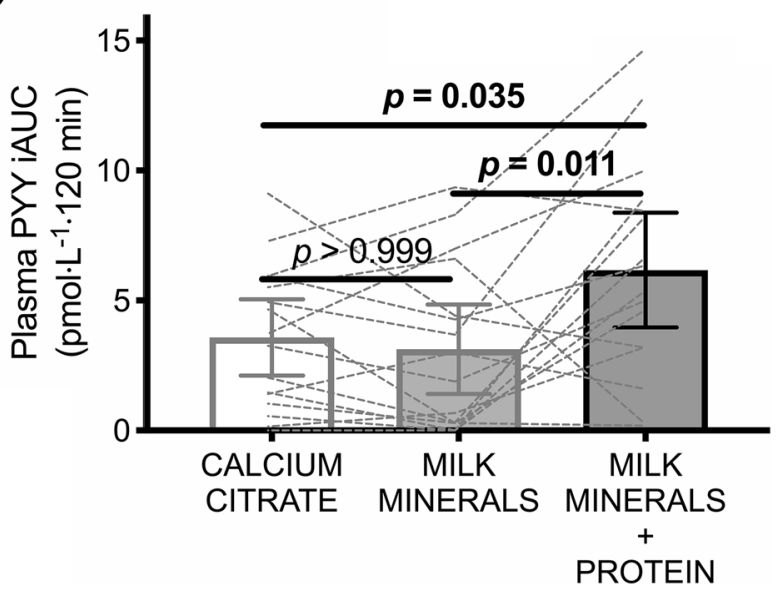

other than PYY, which are $n=16$. GLP-1 glucagon-like peptide-1, GIP glucose-dependent insulinotropic polypeptide, $P Y Y$ peptide tyrosine tyrosine. ${ }^{\mathrm{b}}$ Significant difference between MILK MINERALS + PROTEIN and MILK MINERALS; ${ }^{\mathrm{c} S i g n i f i c a n t ~ d i f f e r e n c e ~}$ between MILK MINERALS + PROTEIN and CITRATE $(p \leq 0.05)$ 
concentrations reached $91 \pm 20 \mathrm{pmol} \mathrm{L}^{-1}$ with MILK MINERALS + PROTEIN, compared to $43 \pm 12 \mathrm{pmol} \mathrm{L}^{-1}$ and $46 \pm 15 \mathrm{pmol} \mathrm{L}^{-1}$ with MILK MINERALS and CALCITR, respectively (both $p<0.001$ versus MILK MINERALS + PROTEIN). Peak GIP concentrations reached $177 \pm 45 \mathrm{pmol} \mathrm{L}^{-1}$ with MILK MINERALS + PROTEIN, compared to $54 \pm 25 \mathrm{pmol} \mathrm{L}^{-1}$ and $52 \pm 25 \mathrm{pmol} \mathrm{L}^{-1}$ with MILK MINERALS and CALCITR, respectively (both $p<0.001$ versus MILK MINERALS + PROTEIN). Peak PYY concentrations reached $93 \pm 55 \mathrm{pmol} \mathrm{L}^{-1}$ with MILK MINERALS + PROTEIN, compared to $81 \pm 46 \mathrm{pmol} \mathrm{L}^{-1}$ and $87 \pm 50 \mathrm{pmol} \mathrm{L}^{-1}$ with MILK MINERALS $(p<0.02)$ and CALCITR $(p=0.64)$, respectively. Furthermore, the iAUC for GIP $(\sim 21$-fold, Fig. $1 \mathrm{c}$; both $p<0.001)$ and PYY ( twofold, Fig. 1d; both $p<0.04)$ were also higher with MILK MINERALS + PROTEIN compared
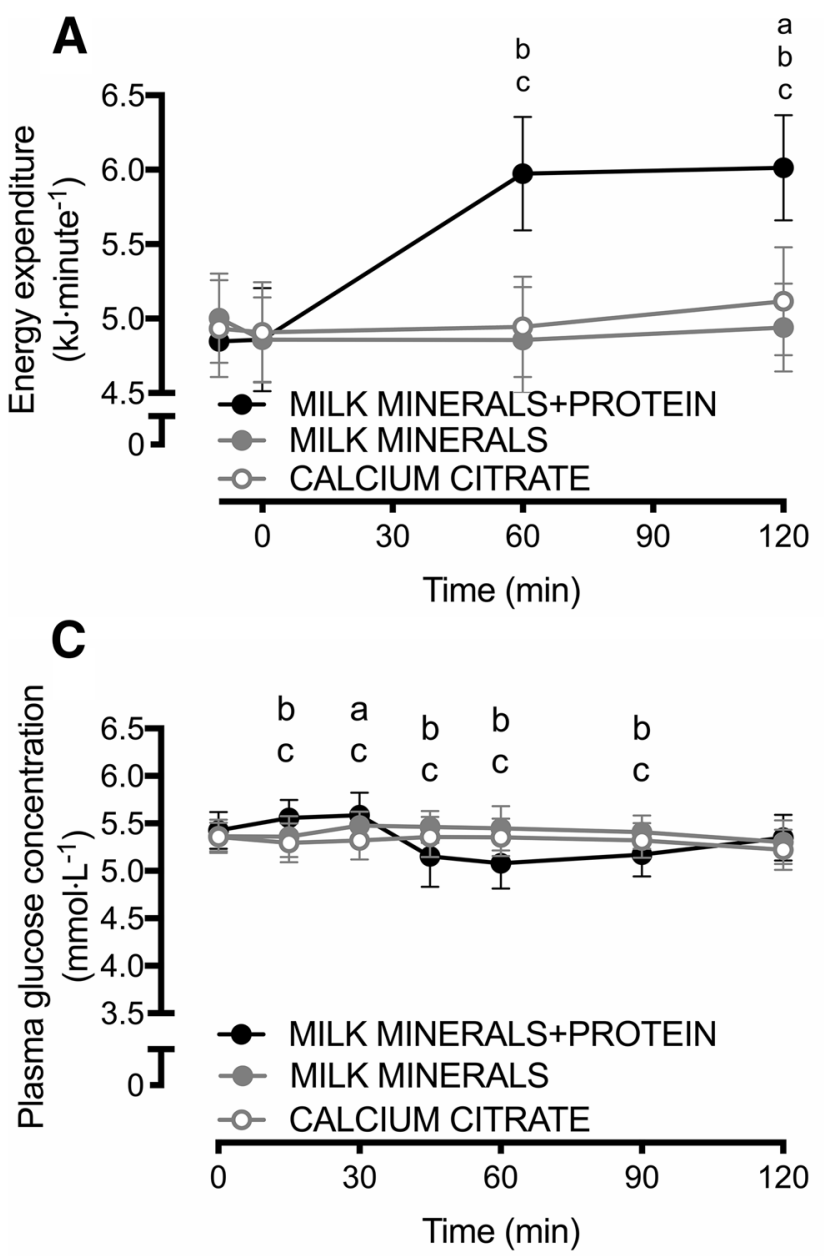

Fig. 2 Energy expenditure (a), respiratory exchange ratio (b), plasma glucose concentrations (c) and time-average postprandial area under the curve (AUC) values for appetite (d) following ingestion of calcium citrate, milk minerals rich in calcium (MILK MINERALS) and MILK MINERALS plus whey protein hydrolysate (MILK MINER- to both CALCITR and MILK MINERALS. No difference in the plasma GLP-1, GIP and PYY iAUCs were detected between MILK MINERALS and CALCITR (Fig. 1b, $p>0.999$; Fig. 1c, $p>0.99$ and Fig. 1d, $p>0.999$, respectively).

Energy expenditure did not differ at baseline $(p=0.14)$. There was a main effect of time, a main effect of treatment, and a time $\times$ treatment interaction effect for energy expenditure (all $p<0.001$ ), whereby MILK MINERALS + PROTEIN increased postprandial energy expenditure by $1.1 \pm 0.4 \mathrm{~kJ} \mathrm{~min}^{-1}$ and $1.0 \pm 0.5 \mathrm{~kJ} \mathrm{~min}^{-1}$ compared to both MILK MINERALS and CALCITR (Fig. 2a, both $p<0.001$; representing an increase of $\sim 21 \%$ ). A main effect of time was also detected for the respiratory exchange ratio (Fig. 2b; $p<0.001$ ), but no main effect of

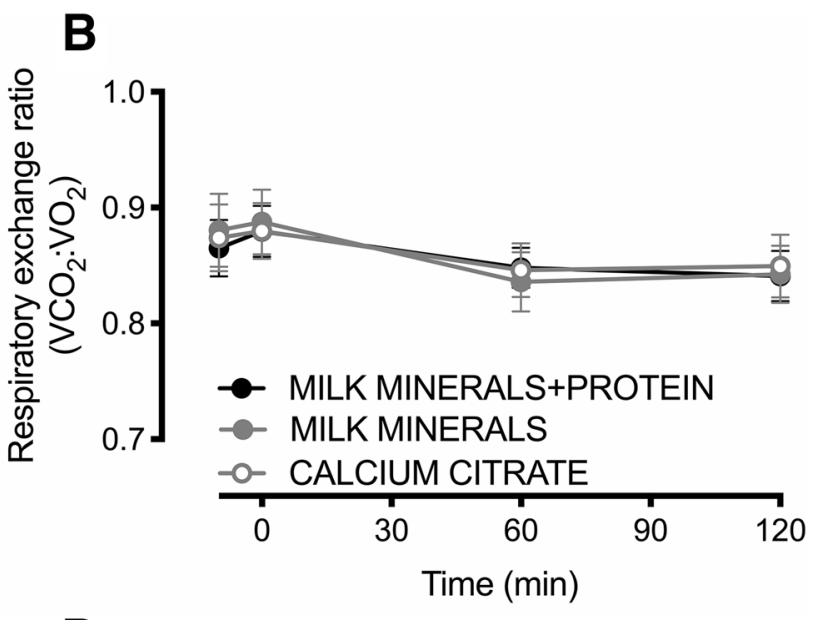

D

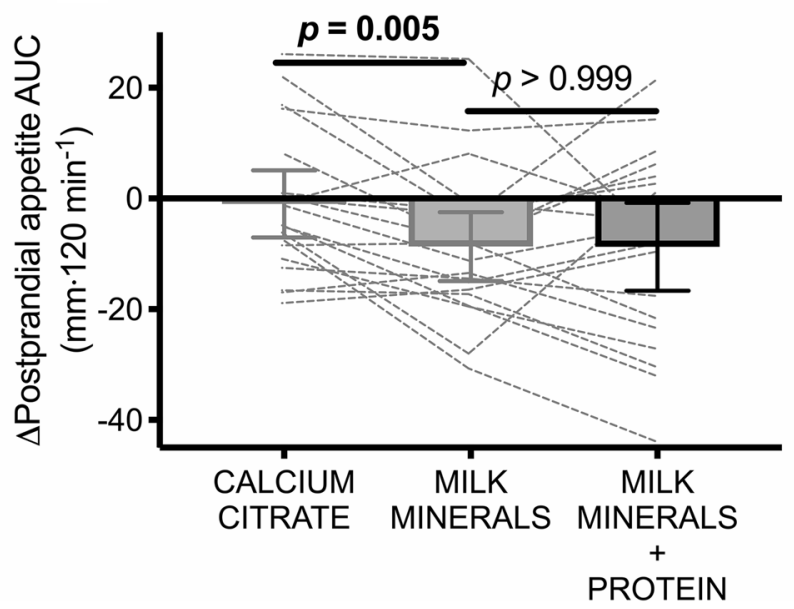

ALS + PROTEIN) in healthy men and women. Data are means $\pm 95 \%$

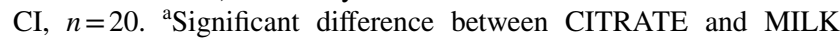
MINERALS; ${ }^{\mathrm{b}}$ Significant difference between MILK MINERALS + PROTEIN and MILK MINERALS; ${ }^{\mathrm{c} S i g n i f i c a n t ~ d i f f e r e n c e ~}$ between MILK MINERALS + PROTEIN and CITRATE $(p \leq 0.05)$ 
treatment, nor any time $\times$ treatment interaction effect was observed for the respiratory exchange ratio (both $p>0.5$ ).

Plasma glucose concentrations did not differ at baseline between any treatment (all $p>0.8$ ). Following ingestion of the test drinks, plasma glucose concentrations demonstrated a main effect of time $(p<0.001)$, and a time $\times$ treatment interaction effect $(p<0.001)$, whereby plasma glucose initially increased, and then decreased with MILK MINERALS + PROTEIN compared to CALCITR and MILK MINERALS (Fig. 2c). However, absolute differences in glucose concentrations were not of a magnitude that is biologically important (maximal difference: $-0.37 \pm 0.51 \mathrm{mmol} \mathrm{L}^{-1}$ ) and plasma glucose concentrations remained within a relatively tight range across all conditions.

Baseline appetite ratings were higher with MILK MINERALS versus CALCITR $(71 \pm 14$ versus $66 \pm 14$ au; $p=0.044$ ), but did not differ between MILK MINERALS + PROTEIN $(70 \pm 16$ au) versus either MILK MINERALS or CALCITR (both $p>0.258$ ). A main effect of time $(p<0.0001)$ and a trend for time $\times$ treatment interaction effect $(p=0.054)$ were detected for postprandial appetite ratings. Accordingly, the postprandial suppression of appetite expressed as an AUC was greater with MILK MINERALS versus CALCITR (Fig. 2d; $p=0.005$ ). No difference in the postprandial suppression of appetite expressed as an AUC was detected between MILK MINERALS and MILK MINERALS + PROTEIN (Fig. 2d; $p>0.999$ ).

Neither systolic blood pressure, nor diastolic blood pressure differed at baseline between treatments (all $p>0.6$ ). No main effects of time or treatment, nor any time $\times$ treatment interaction effects were observed for systolic blood pressure (all $p>0.3$; Fig. 3a). Diastolic blood pressure, however, displayed both a main effect of time $(p=0.033)$ and a main effect of treatment $(p=0.025)$, whereby the MILK MINERALS + PROTEIN produced a diastolic blood pressure than was $1.9 \mathrm{mmHg}$ (95\% CI 0.2-3.6 mmHg) lower than MILK MINERALS (Fig. $3 b ; p=0.092$ ).

\section{Study 2: MILK MINERALS + PROTEIN versus PROTEIN}

Plasma GLP-1 and GIP concentrations did not differ at baseline (both $p>0.99$, but plasma PYY concentrations were higher with PROTEIN versus MILK MINERALS + PROTEIN $\left(23 \pm 6\right.$ versus $15 \pm 3$ pmol L $\left.{ }^{-1} ; p=0.004\right)$. A time $\times$ treatment interaction effect was detected $(p=0.037)$ for postprandial plasma GLP-1 concentrations (Fig. 4a). This resulted in a plasma GLP-1 iAUC that was 25\% higher with MILK MINERALS + PROTEIN compared to PROTEIN (Fig. $4 \mathrm{~b} ; p=0.024$; mean difference: $\left.9.1 \pm 6.9 \mathrm{pmol} \mathrm{L}^{-1} 120 \mathrm{~min}\right)$. A main effect of time was detected for the postprandial change in plasma GIP and PYY concentrations (both, $p<0.001$ ), but no main effect of treatment, nor time $\times$ treatment interaction effect was observed
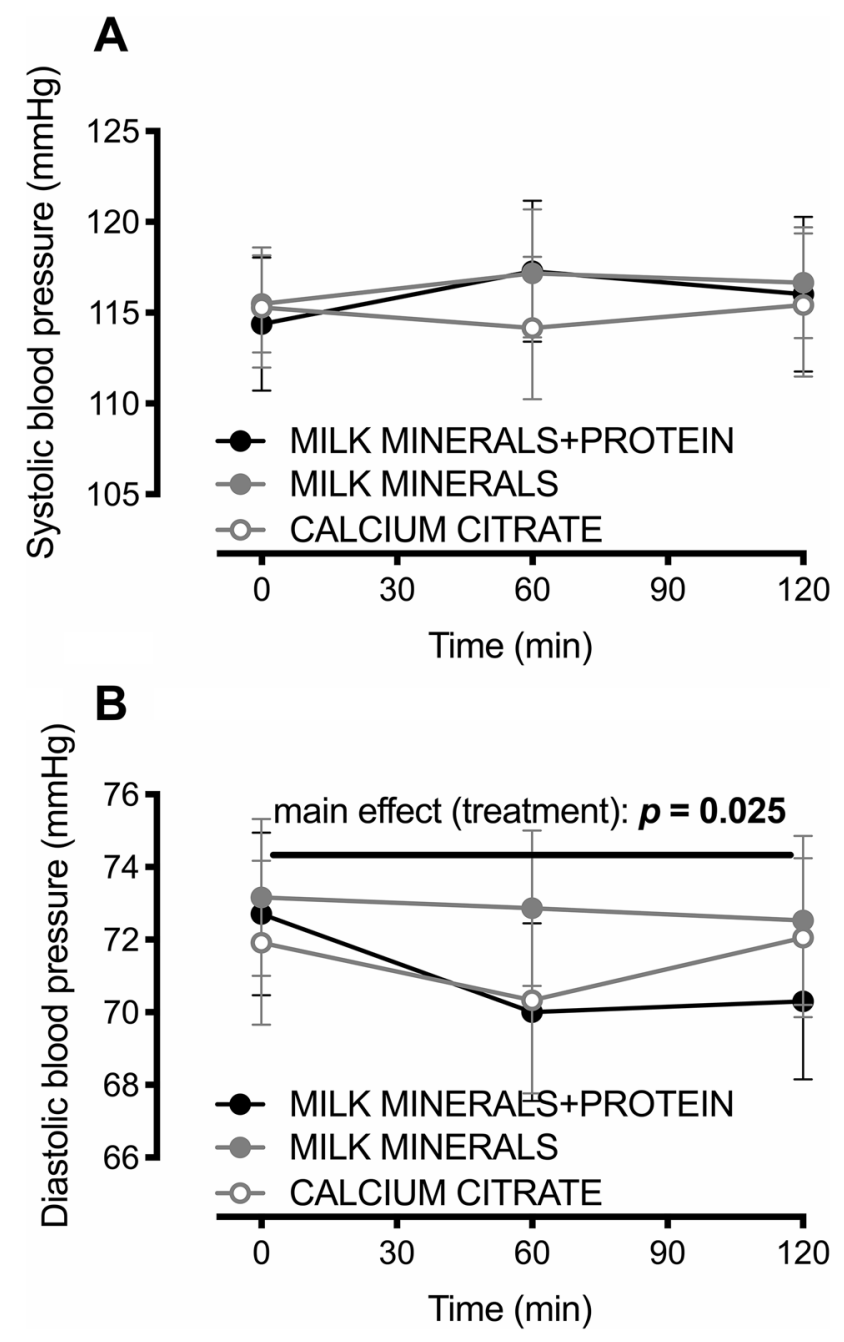

Fig. 3 Systolic (a) and diastolic (b) blood pressure following ingestion of calcium citrate, milk minerals rich in calcium (MILK MINERALS) and MILK MINERALS plus whey protein hydrolysate (MILK MINERALS + PROTEIN) in healthy men and women. Data are means $\pm 95 \% \mathrm{CI}, n=20$

(all $p>0.05$ ). These resulted in a plasma GIP iAUC (Fig. 4c; $p=0.696$ ) and PYY iAUC (Fig. $4 \mathrm{~d} ; p=0.438$ ) that did not differ between MILK MINERALS + PROTEIN and PROTEIN.

\section{Study 3: MILK MINERALS versus CONTROL}

Baseline GLP-1 concentrations (but not GIP, nor PYY concentrations) were higher in the MILK MINERALS trial versus CONTROL ( $36 \pm 15$ versus $\left.25 \pm 11 \mathrm{pmol} \mathrm{L}^{-1} ; p=0.02\right)$. There was a main effect of treatment $(p=0.01)$, but no main effects of time $(p=0.07)$ nor a time $\times$ treatment interaction effect $(p=0.58)$ for postprandial plasma GLP-1 concentrations (Fig. 5a). The increase in the plasma iAUC with MILK MINERALS versus CONTROL was therefore trivial (Fig. 5b; 

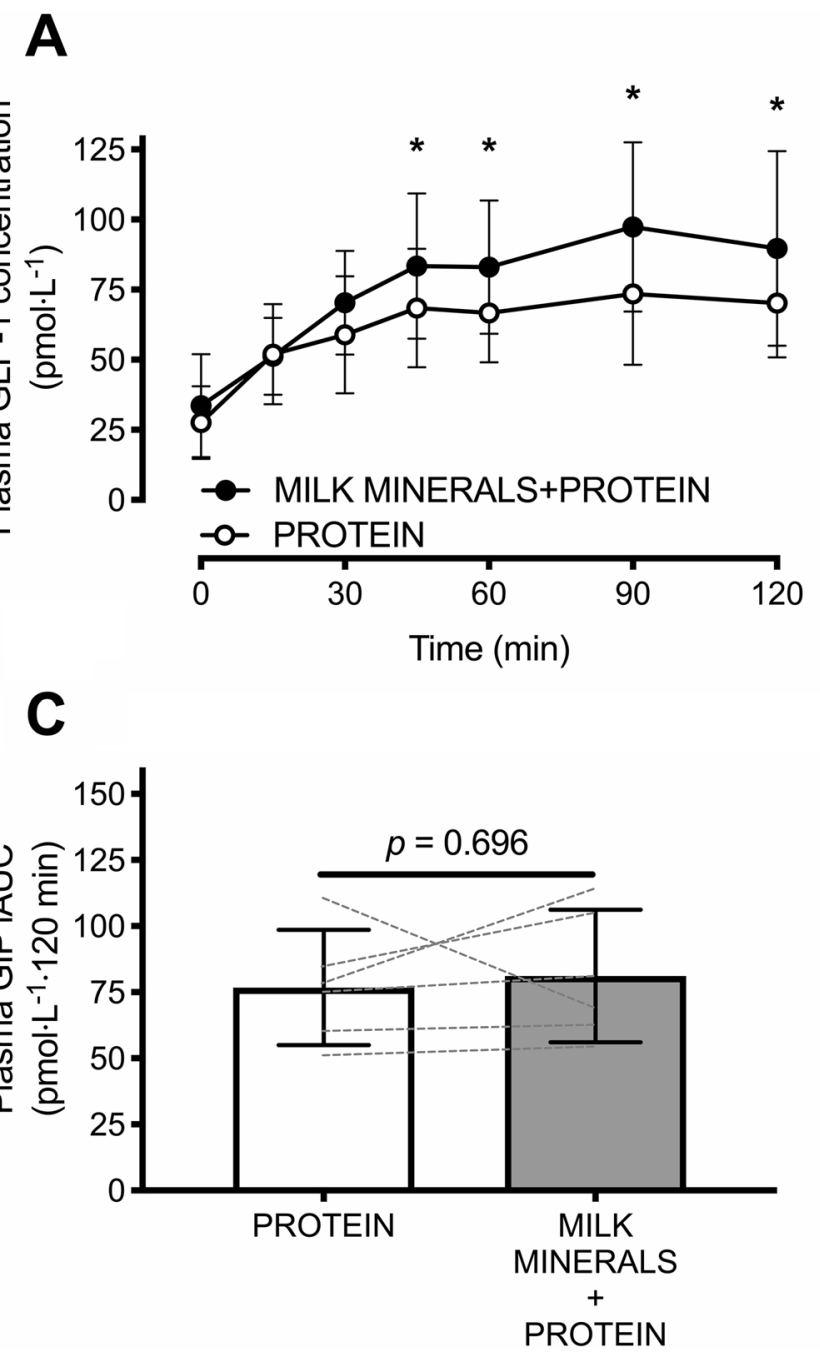

Fig. 4 Plasma GLP-1 concentrations (a) and time-average incremental area under the curve (iAUC) values for plasma GLP-1 (b), GIP (c) and PYY (d) following ingestion of whey protein hydrolysate in the presence (MILK MINERALS + PROTEIN) and absence (PROTEIN)

$p=0.098$; mean difference: $\left.4.2 \pm 5.1 \mathrm{pmol} \mathrm{L}^{-1} 120 \mathrm{~min}\right)$. A main effect of time was detected for the postprandial change in plasma GIP concentrations ( $p=0.04)$, but no main effect of treatment, or time $\times$ treatment interaction effect was observed (both $p>0.7$ ). No main effects of time or treatment, nor time $\times$ treatment interaction effect was observed in plasma PYY (all $p>0.1$ ). Accordingly, no difference was detected in the plasma iAUC for GIP (Fig. 5c; $p=0.688$ ) and PYY (Fig. $5 \mathrm{~d} ; p=0.112$ ) between MILK MINERALS and CONTROL.
B
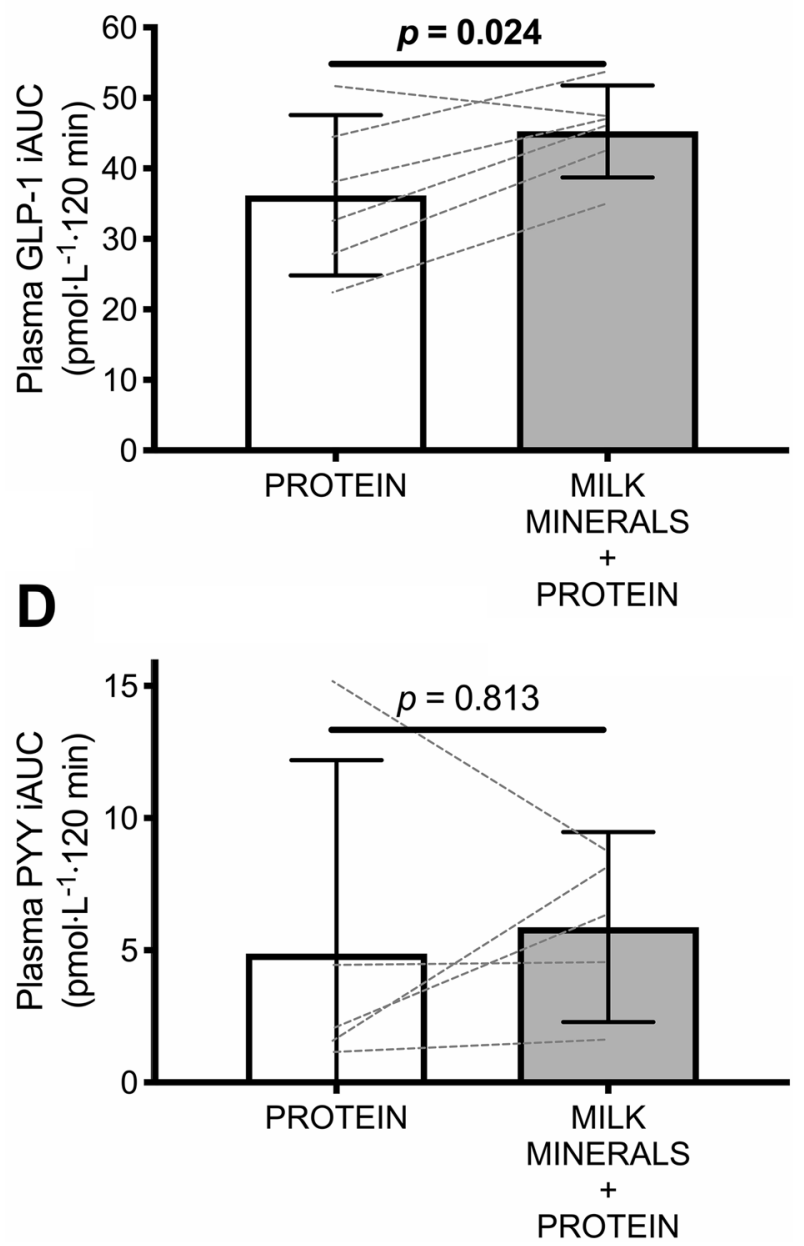

of milk minerals rich in calcium in healthy men and women. Data are means $\pm 95 \% \mathrm{CI}, n=6$. GLP-1 glucagon-like peptide-1, GIP glucosedependent insulinotropic polypeptide, $P Y Y$ peptide tyrosine tyrosine. $*$ Significant difference between treatments $(p \leq 0.05)$

\section{Discussion}

The present work demonstrates that co-ingestion of whey protein hydrolysate with milk minerals rich in calcium potently stimulates plasma GLP-1 availability. Furthermore, milk minerals rich in calcium appear to suppress appetite ratings to a greater extent than an equivalent quantity of calcium from calcium citrate when ingested in isolation. Finally, ingestion of whey protein hydrolysate 

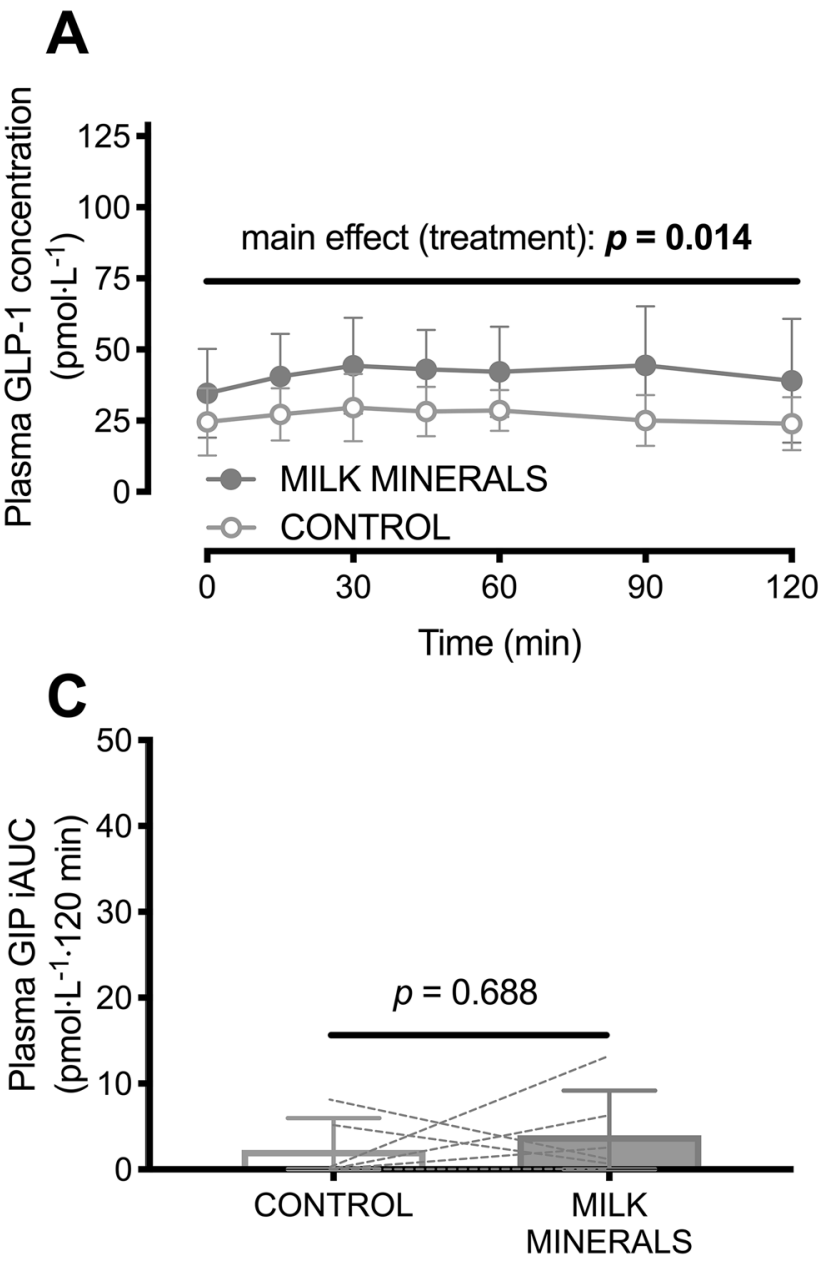

Fig. 5 Plasma GLP-1 concentrations (a) and time-average incremental area under the curve (iAUC) values for plasma GLP-1 (b), GIP (c) and PYY (d) following ingestion of milk minerals rich in calcium (MILK MINERALS) or the vehicle of ingestion (CONTROL;

plus milk minerals rich in calcium, but not calcium alone, acutely reduces diastolic blood pressure.

There are mounting rodent data suggesting that calcium plays an important role in amino acid-induced gut hormone secretion. Ex vivo intestinal perfusion demonstrates that the calcium concentration of the environment is essential for robust amino acid-induced GLP-1 secretion [8], which is thought to act via the synergistic stimulation of the calcium-sensing receptor by both calcium and amino acids $[10,30]$. It has also been demonstrated more recently that the calcium-sensing receptor mediates the effects of amino acids on gut hormone secretion, appetite and food intake in rodents, in vivo [11]. The present study is the first to demonstrate that ingestion of milk minerals rich in calcium further increases whey protein-induced postprandial GLP-1 secretion in humans. Increasing postprandial GLP-1 concentrations is a key target for improving metabolic health and/ or decreasing obesity risk by stimulating insulin secretion
B
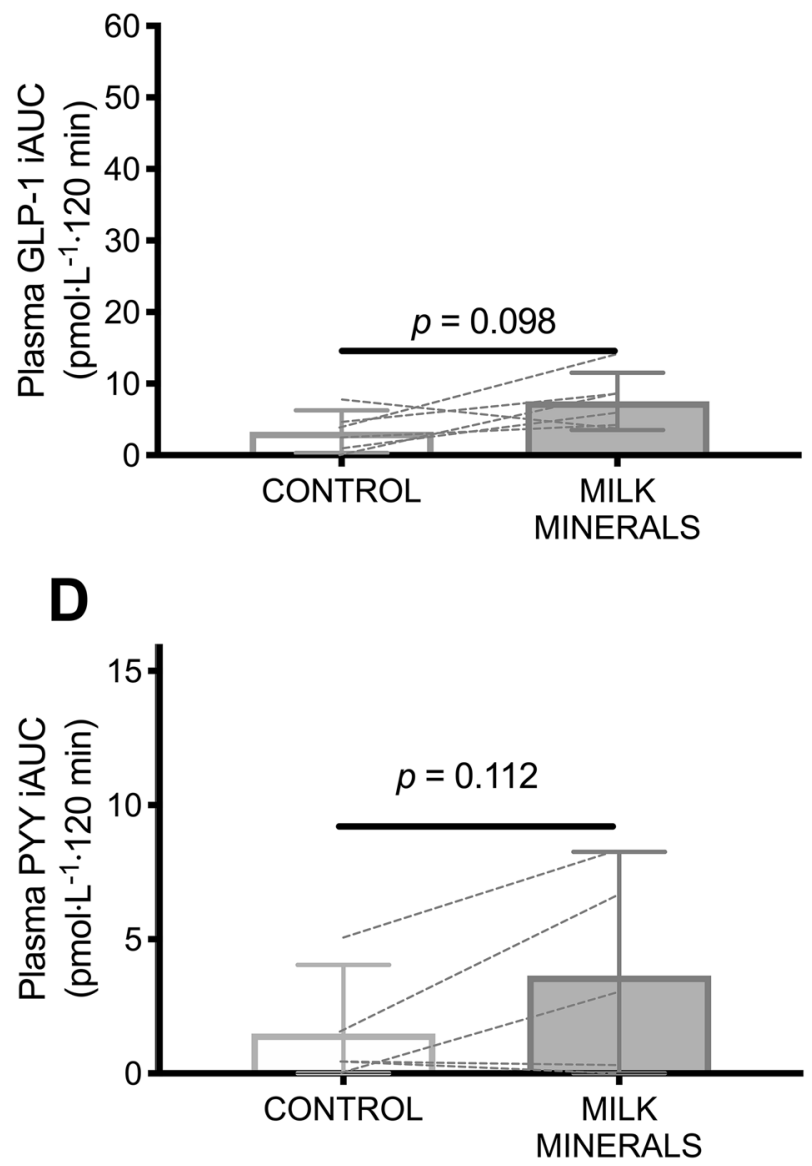

$500 \mathrm{~mL}$ water plus $80 \mathrm{mg}$ sucralose) in healthy men and women. Data are means $\pm 95 \%$ CI, $n=6$. GLP-1 glucagon-like peptide- $1, G I P$ glucose-dependent insulinotropic polypeptide, $P Y Y$ peptide tyrosine tyrosine

and angiogenesis, whilst suppressing appetite and energy intake [1-3].

The postprandial GLP-1 concentrations in the current study are some of the highest ever reported in physiological conditions. Importantly, fasting concentrations were in line with those reported by others in similar healthy populations, typically between 20 and $40 \mathrm{pmol} \mathrm{L}^{-1}$ [29, 31, 32], yet the combined ingestion of $\sim 1000 \mathrm{mg}$ milk minerals rich in calcium with $50 \mathrm{~g}$ whey protein hydrolysate produced remarkably high plasma GLP-1 concentrations. The mean peak postprandial concentrations $\left(91 \pm 20 \mathrm{pmol} \mathrm{L}^{-1}\right)$ are more than double that reported with whey protein ingestion in a similar healthy population, even with $70 \mathrm{~g}$ whey protein isolate ingested orally [31], or $50 \mathrm{~g}$ administered via intraduodenal infusion [29]. Furthermore, peak GLP-1 concentrations with Roux-en-Y gastric bypass surgery have been shown to increase from $\sim 20$ pmol L ${ }^{-1}$ pre-surgery, to $\sim 100$ pmol L ${ }^{-1}$ post-surgery [33]. The dose of protein 
used in the present study is still relatively high from a practical perspective, and therefore the effects of protein and calcium co-ingestion should be explored with lower doses in the future. Nevertheless, the postprandial plasma concentrations of GLP-1 that we report are therefore some of the highest in the literature with physiological ingestion of nutrients.

The reasons for the remarkably high GLP-1 concentrations observed here could be due to: (1) the GLP-1 assay method, (2) the use of arterialized blood sampling, and/or (3) the co-ingestion of calcium with whey protein hydrolysate. First, the assay employed in the present study has been shown to have good precision and specificity for GLP$1_{\text {Total }}[24]$. Furthermore, the basal concentrations we report are in line with previous studies in similar cohorts [29, 31], and ELISAs can tend to under-estimate GLP-1 concentrations compared to radioimmunoassays [24]. Therefore, the high concentrations we report are not likely to be an artefact of the assay employed.

Regarding the second possibility, GLP-1 concentrations are higher in arterial, compared to venous blood [34, 35], presumably due to tissue uptake or binding with GLP-1 receptors. Therefore, as with glycaemia [22], it may be recommended to sample from arterial or arterialized blood when systemic postprandial gut hormone concentrations require accurate quantification. However, the difference in peak postprandial GLP- $1_{\text {Total }}$ concentrations between arterialized and venous blood is $\sim 10 \mathrm{pmol} \mathrm{L}^{-1}$ [35]. Consequently, the blood sampling method employed can only explain a small fraction of the remarkably high GLP-1 concentrations that we report. It is, therefore, highly likely that the primary reason for the high GLP-1 concentrations in the present study is the potency of the milk minerals rich in calcium plus whey protein hydrolysate test-drink.

Theoretically, the exceptionally high concentrations of GLP-1 reported in the present study could be due to the ingestion of whey protein hydrolysate increasing intestinal $\mathrm{K}$ - and L-cell exposure to amino acids to a greater extent than other (non-hydrolysed) protein sources that have previously been investigated [30]. However, the ingestion of $50 \mathrm{~g}$ albumin has been shown to increase ileal concentrations of free amino acids to $20 \mathrm{mmol} \mathrm{L}^{-1}$ [36], which is already $\sim$ twofold higher than the concentration thought to maximize GLP-1 secretion in the presence or absence of calcium [8]. Therefore, any potential further increase in free amino acid availability with whey protein hydrolysate is unlikely to further stimulate GLP-1 secretion and thus, the co-ingestion of calcium with protein is the most likely explanation for the exceptionally high postprandial GLP-1 concentrations we report. To confirm this, we performed a second study, which demonstrated that the addition of milk minerals rich in calcium to whey protein hydrolysate further increases postprandial GLP-1 concentrations by $\sim 25 \%$. Furthermore, the calcium-induced increase in
GLP-1 concentrations was more than two-fold in magnitude when ingested with versus without protein (iAUC $\sim 9$ versus $\sim 4$ pmol L ${ }^{-1} 120 \mathrm{~min}$ ). Whilst this requires confirmation as this was not a direct (within-subject) comparison, this suggests that the ability of milk minerals rich in calcium to influence GLP-1 secretion may be partly dependent on coingestion of protein (or other macronutrients). Interestingly, such a synergistic effect was not observed for GIP, nor PYY concentrations, highlighting a potentially important role of calcium in GLP-1 secretion. It remains to be seen whether milk sources of calcium (or minor quantities of other minerals present in the milk mineral mixture enriched in calcium), are of particular importance in GLP-1 secretion.

The ingestion of milk minerals rich in calcium suppressed postprandial subjective appetite ratings to a greater extent than calcium citrate, although this may have been partly driven by baseline differences between these two conditions. Interestingly, there was no further suppression of appetite by the addition of $50 \mathrm{~g}$ whey protein hydrolysate to milk minerals rich in calcium ingestion. We have previously reported that milk minerals rich in calcium suppresses appetite ratings and energy intake independent of milk protein [7]. The present data confirm this response and extend it to whey protein hydrolysate, rather than milk minerals rich in calcium alone. The mechanisms for the suppression in subjective appetite ratings are unclear and cannot be explained by changes in GLP-1 or PYY concentrations. Whilst GLP-1 and PYY contribute to appetite regulation, it is possible that other mechanisms such as alterations in gastric emptying, or other gut hormones such as cholecystokinin or OXM could be influenced by calcium ingestion in a way that would suppress appetite and supersede the changes in GLP-1 observed in the present study. These potential mechanisms require further exploration. There is also a need to understand whether these changes in gut hormone availability translate into changes in insulinaemia and/or ad libitum energy intake (sufficient to offset the higher energy load of protein co-ingestion).

Whey protein hydrolysate also produced a robust increase in energy expenditure. Protein stimulates postprandial thermogenesis to a greater extent than other macronutrients, and whey protein stimulates postprandial thermogenesis more than other protein sources [37]. The increase in energy expenditure in the current study is in close agreement $\left(\sim 1 \mathrm{~kJ} \mathrm{~min}{ }^{-1}\right.$, equivalent to $\sim 16 \mathrm{kcal}$ per hour) with that reported by others [37]. Therefore, the combination of milk minerals rich in calcium with whey protein hydrolysate produces a scenario of enhanced GLP-1 secretion, suppressed appetite ratings, and increased resting energy expenditure (albeit the increase in resting energy expenditure is modest in the context of energy balance). Since some gut hormones are also implicated in physical activity energy expenditure [38], it remains to be seen whether this nutritional combination 
also stimulates physical activity energy expenditure (and/or affects energy intake), thereby further contributing to weight control and metabolic health.

Both dietary calcium and whey protein have been implicated in blood pressure reduction, albeit with an equivocal evidence base [39, 40]. Here we demonstrate that neither calcium citrate nor milk sources of calcium acutely alter blood pressure, whereas whey protein hydrolysate plus milk minerals rich in calcium acutely reduces diastolic blood pressure by $\sim 2 \mathrm{mmHg}$. It should be noted that the present study design did not contain an isocaloric comparator to whey protein hydrolysate ingestion, and it is unknown whether the responses to protein ingestion were macronutrient-specific or due to the higher energy load in that trial. Furthermore, heart rate was not measured in the present study, and therefore it is not possible to assess whether a compensatory increase in heart rate was observed in response to the lowering of blood pressure. Nevertheless, other work has demonstrated that whey protein ingestion can acutely lower systolic blood pressure compared to isocaloric maltodextrin ingestion, without any evidence of compensatory increases in heart rate [39]. Longer-term studies are required to assess whether this acute $2 \mathrm{mmHg}$ reduction in blood pressure translates into chronic changes in blood pressure of a meaningful magnitude.

In conclusion, this collective series of studies is the first to show that whey protein hydrolysate potently stimulates GLP-1 secretion, and that this response can be further enhanced (albeit modestly) by the co-ingestion of dietary calcium. It remains to be established if this is a proteinspecific (or energy-specific) response. Nevertheless, this suggests that the addition of calcium to protein ingestion can potentiate postprandial GLP-1 concentrations without further increasing the energy load. In addition, these data demonstrate that milk minerals enriched in calcium suppress appetite to a greater extent than calcium citrate and this suppression does not require the addition of protein. Finally, dietary calcium does not appear to acutely affect blood pressure in healthy men and women.

Acknowledgements The authors thank the volunteers for their time and effort in participating in this study.

Author contributions YCC, UMR, DT, JAB, JS, and JTG designed the research. YCC, HAS, OCS, AH, and HAC conducted the research. YCC and JTG analyzed data and performed statistical analysis. YCC and JTG wrote the paper. JTG had primary responsibility for final content. All authors read and approved the final manuscript.

Funding This work was supported by grants from Arla Foods Ingredients and from The Nutrition Society.

\section{Compliance with ethical standards}

Conflict of interest Y.C.C., H.A.S., A.H., O.C.S., D.T., and J.S. have no conflicts of interest to declare. U.R.M. is an employee of Arla Foods
Ingredients who produce and sell milk minerals enriched in calcium and whey protein hydrolysate. H.A.C. has accepted conference fees from Danone Nutricia and received research funding from the European Hydration Institute. J.A.B. has received research funding from GlaxoSmithKline Nutritional Healthcare R\&D, Lucozade Ribena Suntory and Kelloggs, has acted as a consultant for Lucozade Ribena Suntory and PepsiCo and is a scientific advisor to the International Life Sciences Institute (ILSI) Europe Task Force on Energy Balance. J.T.G. has received research funding from Arla Foods Ingredients, Lucozade Ribena Suntory, The Rank Prize Funds, The European Society for Clinical Nutrition and Metabolism (ESPEN), and Kenniscentrum Suiker and Voeding, and has acted as a consultant for Lucozade Ribena Suntory and PepsiCo.

Open Access This article is distributed under the terms of the Creative Commons Attribution 4.0 International License (http://creativeco mmons.org/licenses/by/4.0/), which permits unrestricted use, distribution, and reproduction in any medium, provided you give appropriate credit to the original author(s) and the source, provide a link to the Creative Commons license, and indicate if changes were made.

\section{References}

1. Drucker DJ (2018) Mechanisms of action and therapeutic application of glucagon-like peptide-1. Cell Metab 27(4):740-756

2. Nauck MA, Meier JJ, Cavender MA, Abd El Aziz M, Drucker DJ (2017) Cardiovascular actions and clinical outcomes with glucagon-like peptide-1 receptor agonists and dipeptidyl peptidase-4 inhibitors. Circulation 136(9):849-870. https://doi.org/10.1161/ CIRCULATIONAHA.117.028136

3. Holst JJ (2007) The physiology of glucagon-like peptide 1. Physiol Rev 87(4):1409-1439. https://doi.org/10.1152/physrev.00034 .2006

4. Pinyo J, Hira T, Hara H (2019) Enhanced postprandial glucagonlike peptide- 1 secretion during obesity development has a protective role against glucose intolerance induction in rats. Br J Nutr. https://doi.org/10.1017/s0007114519001223

5. Picot J, Jones J, Colquitt JL, Gospodarevskaya E, Loveman E, Baxter L, Clegg AJ (2009) The clinical effectiveness and costeffectiveness of bariatric (weight loss) surgery for obesity: a systematic review and economic evaluation. Health Technol Assess 13(41):1-190. https://doi.org/10.3310/hta13410 (215-357, iii-iv)

6. Bendtsen LQ, Lorenzen JK, Bendsen NT, Rasmussen C, Astrup A (2013) Effect of dairy proteins on appetite, energy expenditure, body weight, and composition: a review of the evidence from controlled clinical trials. Adv Nutr 4(4):418-438. https://doi. org/10.3945/an.113.003723

7. Gonzalez JT, Green BP, Brown MA, Rumbold PL, Turner LA, Stevenson EJ (2015) Calcium ingestion suppresses appetite and produces acute overcompensation of energy intake independent of protein in healthy adults. J Nutr 145(3):476-482. https://doi. org/10.3945/jn.114.205708

8. Mace OJ, Schindler M, Patel S (2012) The regulation of K- and L-cell activity by GLUT2 and the calcium-sensing receptor CasR in rat small intestine. J Physiol 590(Pt 12):2917-2936. https://doi. org/10.1113/jphysiol.2011.223800

9. Tolhurst G, Zheng Y, Parker HE, Habib AM, Reimann F, Gribble FM (2011) Glutamine triggers and potentiates glucagon-like peptide- 1 secretion by raising cytosolic $\mathrm{Ca} 2+$ and cAMP. Endocrinology 152(2):405-413

10. Conigrave AD, Brown EM (2006) Taste receptors in the gastrointestinal tract. II. L-amino acid sensing by calcium-sensing 
receptors: implications for GI physiology. Am J Physiol Gastrointest Liver Physiol 291(5):G753-G761

11. Alamshah A, Spreckley E, Norton M, Kinsey-Jones JS, Amin A, Ramgulam A, Cao Y, Johnson R, Saleh K, Akalestou E, Malik Z, Gonzalez-Abuin N, Jomard A, Amarsi R, Moolla A, Sargent PR, Gray GW, Bloom SR, Murphy KG (2017) 1-phenylalanine modulates gut hormone release and glucose tolerance, and suppresses food intake through the calcium-sensing receptor in rodents. Int $\mathrm{J}$ Obes 41(11):1693-1701. https://doi.org/10.1038/ijo.2017.164

12. Gonzalez JT, Stevenson EJ (2014) Calcium co-ingestion augments postprandial glucose-dependent insulinotropic peptide 1-42, glucagon-like peptide- 1 and insulin concentrations in humans. Eur J Nutr 53(2):375-385. https://doi.org/10.1007/s00394-013-0532-8

13. Trautvetter U, Jahreis G (2013) Effect of supplementary calcium phosphate on plasma gastrointestinal hormones in a double-blind, placebo-controlled, cross-over human study. Br J Nutr. https://doi. org/10.1017/s0007114513002341

14. Lorenzen JK, Nielsen S, Holst JJ, Tetens I, Rehfeld JF, Astrup A (2007) Effect of dairy calcium or supplementary calcium intake on postprandial fat metabolism, appetite, and subsequent energy intake. Am J Clin Nutr 85(3):678-687

15. Gonzalez JT, Green BP, Campbell MC, Rumbold PL, Stevenson EJ (2014) The influence of calcium supplementation on substrate metabolism during exercise in humans: a randomized controlled trial. Eur J Clin Nutr 68(6):712-718. https://doi.org/10.1038/ ejen.2014.41

16. Mortensen K, Christensen LL, Holst JJ, Orskov C (2003) GLP-1 and GIP are colocalized in a subset of endocrine cells in the small intestine. Regul Pept 114(2-3):189-196

17. Fordtran JS, Locklear TW (1966) Ionic constituents and osmolality of gastric and small-intestinal fluids after eating. Am J Dig Dis 11(7):503-521

18. Thomas SD, Need AG, Tucker G, Slobodian P, O'Loughlin PD, Nordin BE (2008) Suppression of parathyroid hormone and bone resorption by calcium carbonate and calcium citrate in postmenopausal women. Calcif Tissue Int 83(2):81-84. https://doi.org/10.1007/ s00223-008-9148-z

19. Green JH, Booth C, Bunning R (2003) Postprandial metabolic responses to milk enriched with milk calcium are different from responses to milk enriched with calcium carbonate. Asia Pac J Clin Nutr 12(1):109-119

20. Ma J, Bellon M, Wishart JM, Young R, Blackshaw LA, Jones KL, Horowitz M, Rayner CK (2009) Effect of the artificial sweetener, sucralose, on gastric emptying and incretin hormone release in healthy subjects. Am J Physiol Gastrointest Liver Physiol 296(4):G735-G739. https://doi.org/10.1152/ajpgi.90708.2008

21. Compher C, Frankenfield D, Keim N, Roth-Yousey L, Evidence Analysis Working G (2006) Best practice methods to apply to measurement of resting metabolic rate in adults: a systematic review. J Am Diet Assoc 106(6):881-903. https://doi.org/10.1016/j. jada.2006.02.009

22. Edinburgh RM, Hengist A, Smith HA, Betts JA, Thompson D, Walhin JP, Gonzalez JT (2017) Prior exercise alters the difference between arterialised and venous glycaemia: implications for blood sampling procedures. Br J Nutr 117(10):1414-1421. https://doi. org/10.1017/S0007114517001362

23. Deacon CF, Holst JJ (2009) Immunoassays for the incretin hormones GIP and GLP-1. Best Pract Res Clin Endocrinol Metab 23(4):425432. https://doi.org/10.1016/j.beem.2009.03.006

24. Bak MJ, Wewer Albrechtsen NJ, Pedersen J, Knop FK, Vilsboll T, Jorgensen NB, Hartmann B, Deacon CF, Dragsted LO, Holst JJ (2014) Specificity and sensitivity of commercially available assays for glucagon-like peptide-1 (GLP-1): implications for GLP-1 measurements in clinical studies. Diabetes Obes Metab 16(11):11551164. https://doi.org/10.1111/dom.12352
25. Betts JA, Thompson D (2012) Thinking outside the bag (not necessarily outside the lab). Med Sci Sports Exerc 44(10):2040. https:// doi.org/10.1249/mss.0b013e318264526f (author reply 2041)

26. Flint A, Raben A, Blundell JE, Astrup A (2000) Reproducibility, power and validity of visual analogue scales in assessment of appetite sensations in single test meal studies. Int J Obes Relat Metab Disord 24(1):38-48

27. Anderson GH, Catherine NL, Woodend DM, Wolever TM (2002) Inverse association between the effect of carbohydrates on blood glucose and subsequent short-term food intake in young men. Am J Clin Nutr 76(5):1023-1030

28. Luttikhold J, van Norren K, Rijna H, Buijs N, Ankersmit M, Heijboer AC, Gootjes J, Hartmann B, Holst JJ, van Loon LJ, van Leeuwen PA (2016) Jejunal feeding is followed by a greater rise in plasma cholecystokinin, peptide YY, glucagon-like peptide 1, and glucagon-like peptide 2 concentrations compared with gastric feeding in vivo in humans: a randomized trial. Am J Clin Nutr 103(2):435-443. https ://doi.org/10.3945/ajen.115.116251

29. Hutchison AT, Feinle-Bisset C, Fitzgerald PC, Standfield S, Horowitz M, Clifton PM, Luscombe-Marsh ND (2015) Comparative effects of intraduodenal whey protein hydrolysate on antropyloroduodenal motility, gut hormones, glycemia, appetite, and energy intake in lean and obese men. Am J Clin Nutr 102(6):1323-1331. https://doi.org/10.3945/ajcn.115.114538

30. Conigrave AD, Quinn SJ, Brown EM (2000) L-amino acid sensing by the extracellular Ca2+-sensing receptor. Proc Natl Acad Sci USA 97(9):4814-4819

31. Hutchison AT, Piscitelli D, Horowitz M, Jones KL, Clifton PM, Standfield S, Hausken T, Feinle-Bisset C, Luscombe-Marsh ND (2015) Acute load-dependent effects of oral whey protein on gastric emptying, gut hormone release, glycemia, appetite, and energy intake in healthy men. Am J Clin Nutr 102(6):1574-1584. https:// doi.org/10.3945/ajcn.115.117556

32. Giezenaar C, Trahair LG, Luscombe-Marsh ND, Hausken T, Standfield S, Jones KL, Lange K, Horowitz M, Chapman I, Soenen S (2017) Effects of randomized whey-protein loads on energy intake, appetite, gastric emptying, and plasma gut-hormone concentrations in older men and women. Am J Clin Nutr 106(3):865-877. https:// doi.org/10.3945/ajcn.117.154377

33. Laferrere B, Heshka S, Wang K, Khan Y, McGinty J, Teixeira J, Hart AB, Olivan B (2007) Incretin levels and effect are markedly enhanced 1 month after Roux-en-Y gastric bypass surgery in obese patients with type 2 diabetes. Diabetes Care 30(7):1709-1716. https ://doi.org/10.2337/dc06-1549

34. Asmar A, Asmar M, Simonsen L, Madsbad S, Holst JJ, Hartmann B, Sorensen CM, Bulow J (2017) Glucagon-like peptide-1 elicits vasodilation in adipose tissue and skeletal muscle in healthy men. Physiol Rep. https://doi.org/10.14814/phy2.13073

35. Chen YC, Edinburgh RM, Hengist A, Smith HA, Walhin JP, Betts JA, Thompson D, Gonzalez JT (2018) Venous blood provides lower GLP-1 concentrations than arterialised blood in the postprandial, but not fasted state: consequences of sampling methods. Exp Physiol 103(9):1200-1205. https://doi.org/10.1113/EP087118

36. Adibi SA, Mercer DW (1973) Protein digestion in human intestine as reflected in luminal, mucosal, and plasma amino acid concentrations after meals. J Clin Investig 52(7):1586-1594. https://doi. org/10.1172/JCI107335

37. Acheson KJ, Blondel-Lubrano A, Oguey-Araymon S, Beaumont M, Emady-Azar S, Ammon-Zufferey C, Monnard I, Pinaud S, NielsenMoennoz C, Bovetto L (2011) Protein choices targeting thermogenesis and metabolism. Am J Clin Nutr 93(3):525-534. https://doi. org/10.3945/ajen.110.005850

38. Wynne K, Park AJ, Small CJ, Meeran K, Ghatei MA, Frost GS, Bloom SR (2006) Oxyntomodulin increases energy expenditure in addition to decreasing energy intake in overweight and obese 
humans: a randomised controlled trial. Int J Obes 30(12):17291736. https://doi.org/10.1038/sj.ijo.0803344

39. Hofmeyr GJ, Seuc AH, Betrán AP, Purnat TD, Ciganda A, Munjanja SP, Manyame S, Singata M, Fawcus S, Frank K, Harr DR, Cormick G, Roberts JM, Bergel EF, Drebit SK, Von Dadelszen P, Belizan JM, Group CaP-eS (2015) The effect of calcium supplementation on blood pressure in non-pregnant women with previous pre-eclampsia: an exploratory, randomized placebo controlled study. Pregnancy Hypertens 5(4):273-279

40. Fekete ÁA, Giromini C, Chatzidiakou Y, Givens DI, Lovergrove JA (2018) Whey protein lowers systolic blood pressure and Cacaseinate reduces serum TAG after a high-fat meal in mildly hypertensive adults. Sci Rep 8(1):5026 